\title{
Equality and ethnic minorities
}

Sonali Campion and Ros Taylor examine the extent to which the media and political representation of ethnic minorities in the UK, and their consequent treatment in public policy terms, tend to foster democratic public life. Where previous historical inequalities and discrimination against ethnic minorities are being rectified, is the pace of recent change fast enough? Are there areas where UK society is moving backwards in terms of tolerance and equality for all?

\section{What does democracy require in terms of ethnic and religious equality?}

Citizens of all ethnicities and religions must enjoy genuine equality in terms of civil rights. They must be free to practice their beliefs and customs (as long as these do not restrict the rights of others).

Political and public life should be organised to maximise the equal chances of minorities to be involved in democratic politics - to vote and stand for election, to take part in party and political processes, to contribute to public debate and policy decisions, and to rise to the top in elected public office.

Employment in the public service sector (and in firms working on public sector contracts) should serve as exemplars of good practice in improving minority representation more broadly.

No minority group should be subject to differential discrimination in political or public life or by the law, nor to prejudicial discussion in terms of public and media discourses.

Where barriers to inclusion clearly exist, public regulation or interventions should be undertaken to secure appropriate and feasible ameliorative actions (consistent with maintaining the civil rights of all citizens). 


\section{Recent developments}

In the 21st century the UK is home to more ethno-religious identities than ever. This diversity has developed over a relatively short period of time, in significant part due to immigration from former UK colonies since the Second World War, and to some in-migration of EU citizens since 1973. Changing attitudes towards religion have also played a part, for example, resulting in a decline in Christian affiliations and a rise in the number of people who identify as Muslim and Hindu.

While increasing multiculturalism and religious variation have the potential to enrich British society, such social changes do present public policy challenges for western liberal democracies. This is particularly the case in the current geopolitical climate, where conflicts in the Middle East and Afghanistan and the rise of Islamic jihadist movements (see Chapter 1.1) have fuelled tensions between communities. More recently, the European migrant crisis and the growth of populist/nationalist Eurosceptic and pro-Brexit sentiments have aggravated some existing divides and added new lines of possible conflict.

Concerns over immigration and social change have clearly contributed to the growing popularity of right-wing populist politicians and there are indications that racist attitudes in the UK are once again on the rise after years in decline. While other social attitudes (such as over gay marriage) have changed quite radically, racial prejudice seems not to have budged at all. Over recent decades, the percentage of British people who describe themselves as somewhat racially prejudiced has never fallen below $25 \%$.

Political responses to external threats have in many cases done little to alleviate tensions. In some areas they may have arguably exacerbated them with clumsy counterradicalisation policies, which focus on tackling extremism rather than addressing disadvantage and promoting integration. For example, the Prevent strategy has been criticised for its 'stigmatising surveillance of one particular [Muslim] community', rather than building the capacity to discuss contentious issues or deliver effective civic education.

One-dimensional reporting about ethnicity and religion has also fed into tensions. One example is The Sun's headline in November 2015 claiming: ' 1 in 5 Brit Muslims' sympathy for jihadis'. The article was based on misrepresented poll data from Survation, who were quick to distance themselves from the unauthorised interpretation of their study. The incident led to both an outcry and mockery on social media and The Sun was eventually forced to admit that its headline was 'significantly misleading'. But not all discriminatory coverage - for example of Romanians and Bulgarians in the run up to the lifting of transnational controls - is called out so effectively.

The rise of UKIP as an anti-immigration, Eurosceptic party up to 2016 also seems to have gone hand-in-hand with a revived acceptance of 'banal racism' in areas of the media and public life. During the Brexit campaign UKIP's 'Breaking Point' poster depicted a crowd of refugees and urged voters to 'break free of the EU'; the image was widely circulated on social media (Figure 1). It was also widely condemned. The trade union Unite called it 'a blatant attempt to incite racial hatred and breach UK race laws', and reported it to the police (without success). Key figures in the official Leave campaign, such as Michael Gove and Chris Grayling, sought to distance themselves and the campaign from this messaging, but the damage was clearly done. 


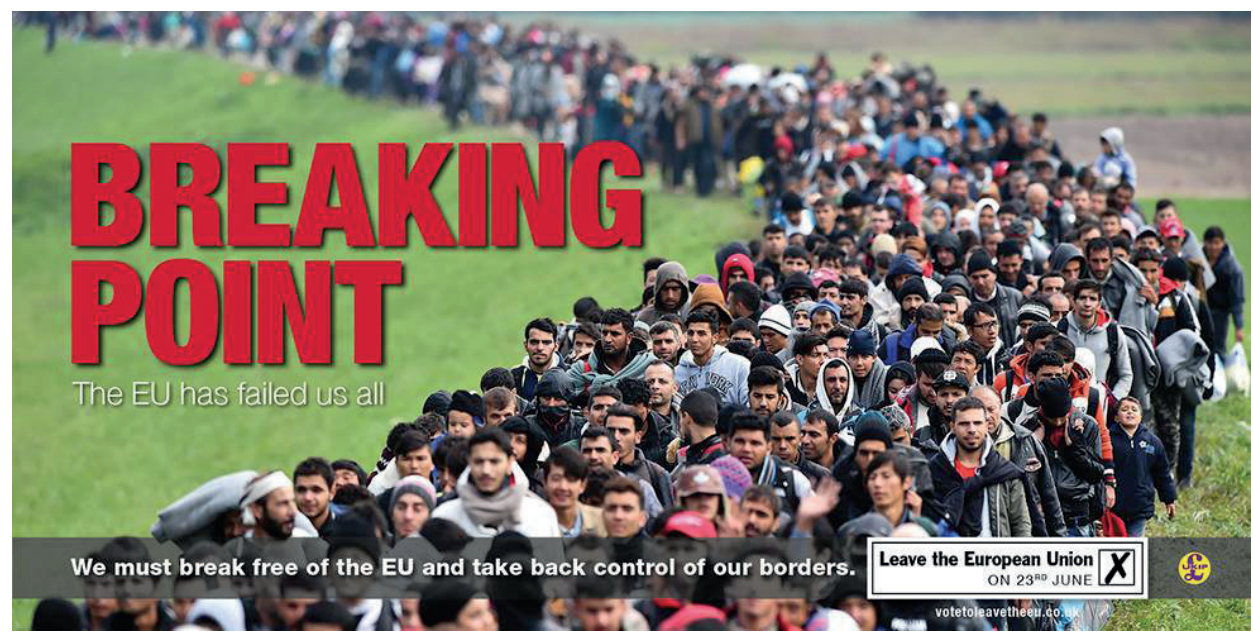

Source: UKIP

In the immediate aftermath of the referendum, both the Muslim Council of Great Britain and the Polish embassy reported outbreaks of racist and xenophobic incidents, including cards reading 'No more Polish vermin' pushed through eastern Europeans' letterboxes. These incidents show a strong anti-immigrant minority view. Such extreme views also seem to receive regular legitimation from tabloid press headlines that repetitively cover immigration issues in an alarmist and stigmatising fashion.

Crime classified as race-related hate crime rose $74 \%$ in England and Wales between 2011/12 and 2016/17 while crime incidents based on religion rose $268 \%$ in the same period. At the same time, the Equality and Human Rights Commission has noted increasing incidents of hate crimes, with racial, Islamophobic or anti-semitic motivations in England. In Scotland, religiously aggravated charges rose 14\% between 2015-16 and 2016-17. (These were often incidents of religious abuse between Catholics and Protestants - a third of the charges recorded were at the Scottish Cup Final, May 2016.) Police noted peaks in race and religious hate crimes: after the murder of soldier Lee Rigby in 2013; after the Charlie Hebdo terrorist attack in Paris in 2015; in July 2016, immediately after the EU referendum (the biggest spike in recent years); and following the terrorist attack on Westminster bridge in March 2017.

Current policy debates around ethnic inequalities and religion and belief are therefore taking place in a highly charged environment, raising new challenges for the UK's traditionally low-key ways of handling these issues.

\section{Mainstream politics and ethnic tensions}

Even mainstream politicians appeared to be adopting 'dog-whistle' strategies to mobilise ethnic and religious divisions for political ends. When Barack Obama reiterated his call for Britain to stay in the EU on a 2016 visit to the UK, prominent Leave campaigners Boris Johnson and Nigel Farage both suggested that the President's 'part-Kenyan' roots were to blame for his ‘anti-British' attitude. 
Early on in his failed London mayoral campaign in 2016, Zac Goldsmith started using the word 'radical' to describe his opponent Sadiq Khan, a Muslim from a Pakistani-origin family. Goldsmith claimed he was using the word to describe the radical politics of the Labour leader Jeremy Corbyn. But media commentators were quick to pick up on the Islamophobic undertones, especially when a Daily Mail article by Goldsmith a week before polling day was illustrated with pictures of London's 7/7 bombings. Goldsmith was also criticised for targeting London's Hindu, Tamil and Sikh communities with leaflets making 'reductive and condescending assumptions' about their priorities, and seeking to mobilise historic tensions between Pakistanis and Indians. Many commentators argued that Goldsmith's defeat by Khan, and his later loss of his Richmond seat to the Liberal Democrats in a parliamentary by-election, can be attributed in a significant part to a backlash against an apparent attempt to exploit or exacerbate London's ethnic divisions for political ends. Accusations of 'Islamophobia' amongst Tory members also resurfaced in 2018. Baroness Warsi called for an independent inquiry, emphasising that 'absolutely nothing tangible has happened' in response to concerns she has raised in relation to antiMuslim prejudice since 2015.

Nor has Labour managed to escape rows over religion and ethnicity. In April 2016 Naz Shah, MP for Bradford West, was suspended for an anti-semitic graphic she shared on Facebook before she was elected. Former Mayor and key Corbyn ally Ken Livingstone then tried to defend Shah and was also suspended from the party as his comments were also viewed as anti-semitic: he later resigned from the party. Jeremy Corbyn at first launched an inquiry into racism in the Labour Party (chaired by Shami Chakrabarti, who was subsequently made a Labour peer), but this was denounced as a whitewash by most Jewish groups.

The controversy continued and burst into flame in the summer of 2018 , focusing on Jeremy Corbyn's past declarations, apparently stalled investigations into other accused Labour members, and Labour's reluctance to adopt the inclusive, international definition of anti-semitism outlined by the International Holocaust Remembrance Alliance (IHRA). Despite Corbyn's repeated denials and public rejection of anti-semitism, a range of Jewish leaders made exceptionally strong personal attacks on him as an alleged 'anti-semite', and in August 2018 the veteran Labour MP Frank Field resigned from the party in protest. In September, Labour finally adopted IHRA's definition in full. The effects of this row on public attitudes remains unclear, but it seem unlikely that it will be positive in combating still widespread (if low level) anti-Jewish prejudice.

\section{The Windrush scandal and ethnic disparities in public policy}

Public servants in the UK generally pride themselves on operating in 'race-blind' ways, and legislation prohibiting any form of race or ethnic discrimination, or impairment of people's human rights is very specific and well-policed. Yet in 2010, when Theresa May became Home Secretary and initiated a 'hostile environment' for illegal migration, the Home Office effectively began discriminating against longstanding UK residents of Caribbean origin who formed part of the 'Windrush generation' that arrived in the late 1950s and early 1960s (see Chapter 5.3). The government eventually admitted to the policy and apologised but not before dozens of elderly people of Caribbean origin were detained and even deported 
back to islands they had left decades before. More widely, it emerged that during this same 'hostile climate' period Home Office officials had made 5,700 changes to the immigration rules, doubling the length of the immigration rulebook and creating a moving target that was hard for migrants and would-be citizens to keep up with.

An early promise of the May government was to conduct a racial disparity audit of UK political institutions in order to "check how race affects how [citizens] are treated on key issues such as health, education and employment, broken down by geographic location, income and gender' and to 'shine a light on how our public services treat people from different backgrounds and influence government policy to solve these problems'. The data was published in October 2017 (much of it collated from other government departments, or dating from the census in 2011), but was welcomed as an important step forward in some areas. For instance, Figure 2 shows that survey evidence suggested little difference between ethnic groups in their contributions to civil society, taken as a measure of 'social capital' - for example ethnic minorities are noticeably more confident than white people that they 'can influence decisions affecting the local area'. Though intended as a means of compelling departments and public bodies to act, it is unclear whether the data will now be used to inform policy and change.

\section{Figure 2: Measures of 'social capital' across ethnic groups in 2017}

Feel they belong to Britain (very or fairly strongly)

Feel they belong to the neighbourhood (very or fairly strongly)

Chat to their neighbours at least once a month

Feel they can influence decisions affecting the local area

Volunteer formally at least once a month

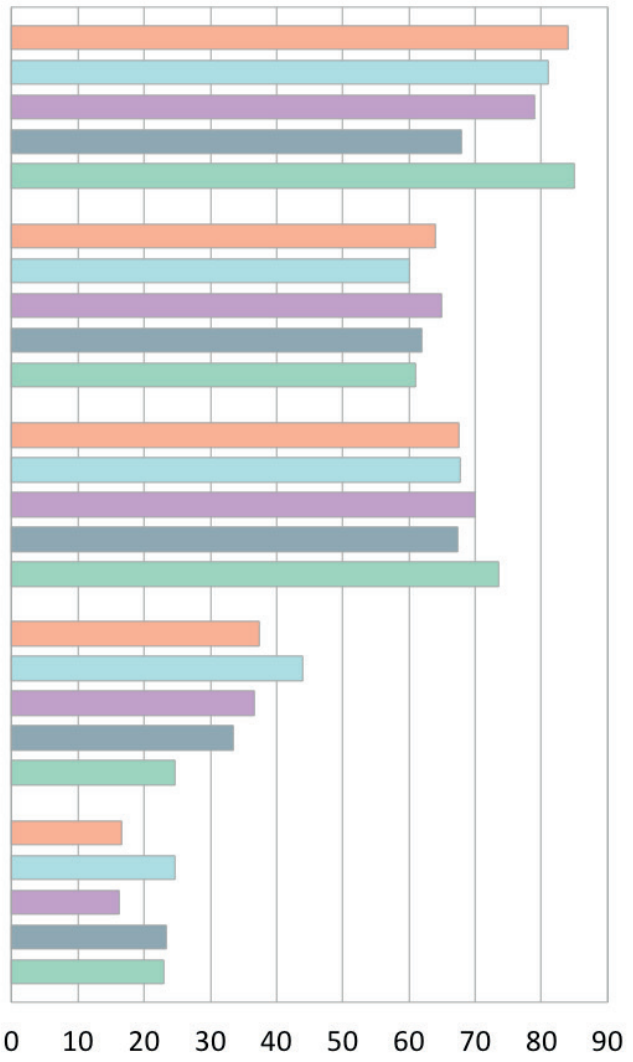

$\square$ Asian $\square$ Black Mixed $\square$ Other $\square$ White

Source: Cabinet Office, Race Disparity Audit 2017, Figure 3.3. (Data from Department for Digital, Culture, Media and Sport, Community Life Survey 2016-17.) 


\section{Strengths, Weaknesses, Opportunities, Threats (SWOT) analysis}

\section{Current strengths}

Politicians in the 'mainstream' parties (especially the Conservatives, Labour, Liberal Democrats, Greens, and the SNP and Plaid Cymru) have normally renounced any resort to 'dog whistle' politics that exploits for partisan ends voters' evident concerns over immigration and the changing social character of some cities. With some prominent exceptions and lapses, political elites held a 'self-restraint' line against exploiting social tensions. In London, recent evidence suggests that this position enjoys wide popular support, but this is not the case elsewhere in the country.

Britain has a reasonable track record of promoting the integration of immigrant communities, particularly when compared to neighbours like France and Belgium.

Austria, Germany, France and Denmark have all witnessed local or national bans on Muslim women's dress that obscures the face. However, there have been few such calls in the UK. In 2018 a much reported press column by Boris Johnson made comments about women who cover their face, which many deemed highly offensive, but argued against any ban.

The proportions of ethnic minorities in UK politics, public life and senior business positions are increasing, albeit relatively slowly. However, some communities are significantly better represented than others, for example, those of Indian origin and descent.

\section{Current weaknesses}

Populist parties and sections of the rightwing press are increasingly stigmatising sections of the population for political/ commercial gain, adding fuel to division and discrimination, and promoting crude stereotypes around minority groups.

The Leave vote in the Brexit referendum was clearly driven by concerns about immigration both of EU migrants, refugees arriving from Europe's neighbours and the possibility of Turkish accession to the EU.

The rise of UKIP has put the previous elite 'self-restraint' ethos on exploiting social tensions under more stress. The stance has become associated with elites' lack of frankness about globalisation and unwillingness to recognise many voters' concerns.

Political responses to immigration issues have tended to focus on economic responses, without fully engaging with cultural concerns held by anti-immigration voters.
Multicultural policies, while they are associated with more peaceful societies, can also make ethnic majorities feel unsafe and discriminated against. 


\section{Future opportunities}

Promoting religious literacy, both at schools and in the workplace, could do much to expand people's awareness of other faiths.

The government has announced recent plans to promote learning English among migrants to offer greater support for tackling discrimination and disadvantage among minority communities - and such provision could easily be expanded. Poor English is worst amongst women in the Bangladeshi. Pakistani, Chinese and Indian communities.

In Germany the potential problems of racism are far greater for historical reasons, and because of recurring violence against immigrants. The federal government there spends substantial sums ( $€ 100 \mathrm{~m}$ in 2017) on political interventions designed to combat racist ideas early on, combined with curbs on the far right. The UK has no similar programmes as yet.

Liberal values (for example, gender equality, sexual minorities and free speech) could be better promoted among ethnic and religious minority communities. But this would need to be done not in a way that targets individual communities with stereotyped assumptions about their existing attitudes.

\section{Future threats}

Since 2016, terrorist attacks in Paris,

Brussels, Manchester and London have prompted a rise in hate crime. Xenophobic violence also surged after the EU referendum.

The evolution of migration pressures on the $\mathrm{EU}$ as a whole, and specifically on the UK (for example, via the now demolished Calais 'jungle' camp) will assuredly influence UK voters' attitudes further after Brexit.

Uncertainty about the future residency status of EU migrants in Britain continues, with fears they may be used as a 'bargaining chip' in Brexit negotiations. The scale and atmosphere of EU migration to the UK (and of UK citizens moving to EU countries also) will be strongly affected by the outcome of Brexit negotiations, with some indications by summer 2018 that EU migration levels have noticeably decreased in advance of the UK's withdrawal.

The major future risk may be that polarisation increases between majority attitudes and those of specific minorities, especially some sections of the Muslim community, accentuating some existing disadvantages.

The government has established a

Controlling Migration Fund, designed to alleviate pressure on councils, schools and $\mathrm{NHS}$ services when a region experiences a large increase in inward migration, and so encourage community cohesion.

We look next at five ongoing issues relating representation in public life: the representation of minorities in political life; ethnic diversity in the media; the treatment of minorities in the criminal justice system, and the education, and employment and income situations of ethnic minorities. 


\section{Representation in political life}

Variations in the understanding of ethnicity have impaired understanding in this area. Where data are collected, they tend to focus on 'black, Asian and minority ethnic' (BAME) people, that is, those of non-white descent. This categorisation is of limited usefulness because it fails to acknowledge the multifaceted nature of the UK's growing diversity. The umbrella label groups the experiences of very different minority communities into one category. It also fails to acknowledge the challenges faced by some white minorities, such as migrants from Eastern Europe. However, due to the limitations of the data and analysis available, we must focus predominantly here on those ethnic minorities included in the BAME category.

The 2016 Annual Population Report found that 13.6\% of the population came from non-white backgrounds. However, minorities remain underrepresented in public life. Although more BAME MPs than ever before (52) were elected in the 2017 general election, the number would have to rise to $\mathbf{8 8}$ for the House of Commons to accurately reflect the population as a whole. More positively, the percentage of ethnic minority female MPs in the House of Commons increased from 1.5\% to 4\% between 2010 and 2017 (with a current total of 26). In government Sajid Javid and Priti Patel were the only non-white members in Theresa May's first cabinet in 2016. Only Javid remains in 2018, though he is the first person from an ethnic minority to become Home Secretary, and to be discussed seriously as future Tory leader.

Figure 3: The percentage of ethnic minorities in various political bodies and populations



Source: House of Commons Library

\section{Diversity in the media}

Ethnic minorities make up $6 \%$ of journalists, though that figure conceals major variation between ethnicities, with black journalists accounting for just $\mathbf{0 . 2} \%$ of the workforce. But 
the problem extends beyond just such numbers. There is a lack of diversity in the kind of stories that are reported. And excluded voices are often only brought in to stories dwelling on extremes or 'otherness'. On the flipside, BAME journalists who do break into the industry are frequently expected to comment on 'minority issues' or those that relate to their 'own communities' while predominantly white male journalists dominate the mainstream. Commentator Nesrine Malik describes how a 'fundamental misunderstanding' of networks can be hermetic and self-perpetuating without being actively racist.

The portrayal of religion and belief in news and current affairs is too often clumsy and lacking in nuance, which has been attributed to a lack of religious literacy among reporters. Studies have noted a foregrounding of stories focusing on the differences between Islam and British/western culture. References to extreme forms of Islam are $\mathbf{2 1}$ times more common than mentions of moderate Muslims. Journalists themselves are far more likely to have no religion (61\%) than the population at large (28\%).

\section{Treatment in the criminal justice and penal systems}

Ethnic minorities continue to be over-represented throughout the criminal justice system. At every stage from being stopped and searched to prison populations, ethno-religious minorities (predominantly those who are black, of mixed parentage, or Muslim) form a majority. Over many years BAME people have been one-and-a-half times as likely to be arrested as whites, as Figure 4 shows. Black people were over three times as likely. BAME groups are also more likely to receive longer sentences. Average custodial sentences vary a bit from year to year, but were 17 months for white defendants, compared to 24-25 months for black or Asian people, and 21 for mixed-race defendants.

Figure 4: The likelihood of being arrested by people's self-defined ethnic group, compared with those from white ethnic groups: England and Wales, year ending March 2017

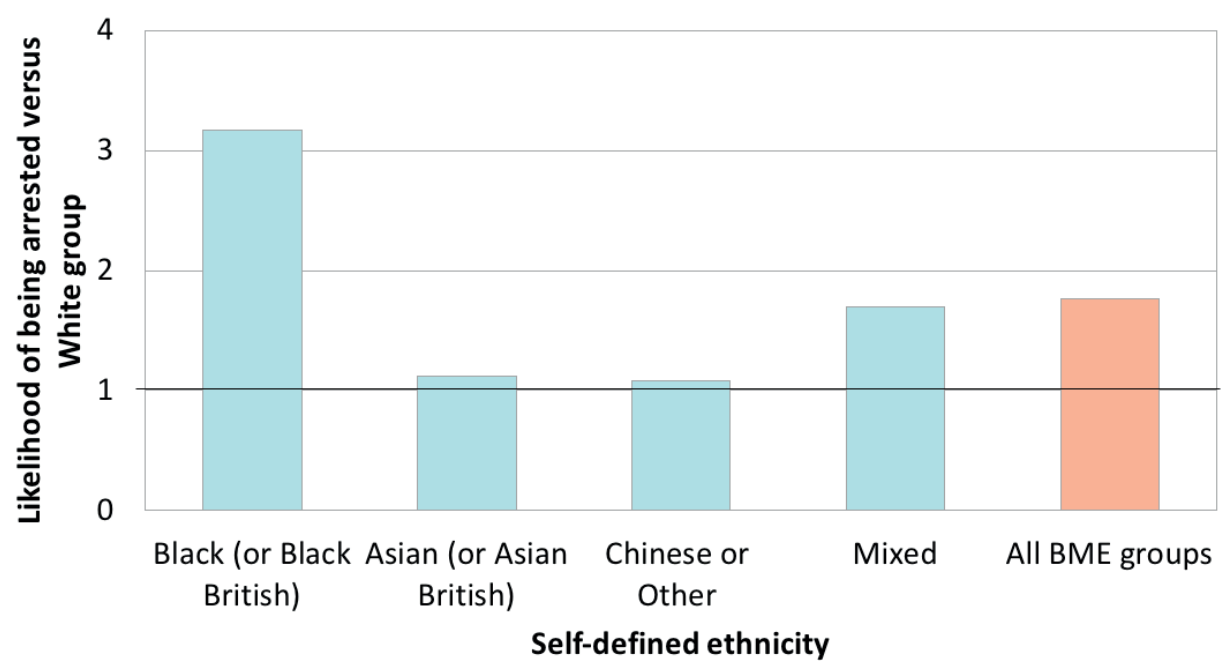

Source: Home Office Figure 3.6.

Note: A score of 1 shows an ethnic group being treated identically with white people; a score above 1 shows a comparatively high arrest rate, and below 1 shows a low arrest rate. 
Data from the Youth Justice Board indicated that in 2014-15, 40\% of prisoners in young offenders' institutions came from a BAME background. In 2016 Muslims accounted for $14.6 \%$ of the prison population, sharply up from $7.7 \%$ in 2002 . Data show that while the percentage of young people in custody has declined since $2004 / 5$, the same proportion has increased for people from black and Asian backgrounds.

The disproportionate numbers of BAME minorities in the justice system is not new, but attempts to address it have so far been unsuccessful. The 2014 Young Review, which looked specifically at the experiences of young male black and/or Muslim offenders, found the disadvantage in BAME communities contributed, along with assumptions based on crude stereotyping or outright racism. These factors made it harder to effectively rehabilitate and reduce reoffending rates among these groups. The report also emphasised that the overrepresentation of ethno-religious minorities 'does not exist in isolation from other unequal outcomes', both in the criminal justice system and other sectors. Likewise, the 2017 Lammy Report found a particular problem with youth prisoners, with the proportion from BAME backgrounds rising from 25\% to $41 \%$ in the decade $2006-16$.

In a few parts of the criminal justice sector, ethnic minorities are well represented in relation to population - notably within the Ministry of Justice and the Crown Prosecution Service. However, they are poorly represented in police forces, judiciary, magistracy and Her Majesty's Prison Service. To counteract this lack of ethnic diversity in the workforce, the Young Review urged pro-active efforts to include organisations and representatives from the offenders' communities and faiths so as to tackle unequal outcomes.

Meanwhile, the proportion of foreign nationals in jail (12\%) has remained fairly stable since 2002. However, they are now much more likely to be Polish $10 \%$ of imprisoned foreign nationals) or Romanian (7\%).

Reforms to civil law justice, such as reductions in the availability of legal aid, adversely affected ethnic minorities more than others, in part because people in these communities tend to be more reliant on legal aid financial support. The 2017 Lammy Report also highlighted a lack of trust in legal aid solicitors which was limiting access to justice by ethnic minority defendants. In addition, many types of immigration and housing cases relevant to BAME groups and Roma are now ineligible for public funding, with Amnesty reporting that migrants and refugees have been disproportionally disadvantaged by changes to legal aid. Monash University's Access to Justice: A Comparative Analysis of Cuts to Legal Aid similarly noted that BAME lawyers were disproportionately represented among those practising in the legal aid sector, and so the cuts could be expected to make the legal profession less diverse. The restoration of legal aid for employment tribunal cases is the only positive sign in this area (see Chapter 7.1).

\section{Education}

In England between 2007/08 and 2015/16, the percentage of undergraduate university entrants from the Asian, black, mixed and other ethnic groups combined increased from $17 \%$ to $23 \%$ However, this improving trend is less marked in Wales and Scotland. Meanwhile gypsy and traveller pupils continue to have the lowest attainment levels of any ethnicity, 
and the gap here has not changed. Furthermore, children from socio-economically disadvantaged backgrounds in England tend to have lower attainment. Although this discrepancy is most pronounced among white boys eligible for free school meals, it is also marked among Asian, black and mixed students.

However, in terms of educational attainments some ethnic minority groups place a lot more emphasis on getting to university. The Race Disparity Audit noted (paragraph 2.12) that:

'Pupils from Pakistani and Bangladeshi backgrounds are achieving almost as well as, and progressing better than, White British pupils, whereas the attainment and progress of Black Caribbean pupils is much lower. White pupils from state schools had the lowest university entry rate of any ethnic group in 2016'.

\section{Employment and income}

Austerity measures under both the David Cameron and Theresa May governments have hit ethnic minorities (alongside women and people with disabilities) the hardest, although it is worth noting that the impact has not been uniform across ethnic groups: Chinese, Indian, Black African communities were affected more than Bangladeshi and Pakistani households. From the outset, the Equality and Human Rights Commission (EHRC) was critical of the government for failing to consider how austerity politics would impact minority groups. However in 2012 the government cut ERHC funding by more than half and stripped it of its duty to foster 'a society with equal opportunity for all'.

Approximately two-fifths of people from ethnic minorities currently live in low-income households (twice the rate of white families). This statistic again varies across groups: more than $50 \%$ of families of Bangladeshi and Pakistani origin live in low-income households, compared to less than $30 \%$ of Indian origin. Research by Alison Donald at Middlesex University attributes the disparity between the white British majority and minorities to the age structure of BAME groups, work status and higher rates of in-work poverty. She also points to changes to social security as penalising the poorest in society to a much greater extent than the richest.

A 2017 report by the Equality and Human Rights Commission examined the occupational pay gap between ethnic groups, defined as 'the average pay gap within individual occupations, in which people do broadly similar work'. They concluded:

Among men, ethnic minorities typically earn less within occupations than their White British counterparts. The picture for women is more mixed, with certain ethnic minorities outperforming [White British] women in terms of pay. However, among both men and women, Bangladeshi and Pakistani people have experienced a large and growing occupational pay gap over time'.

The TUC has identified a $\mathbf{2 3} \%$ pay gap between black and white graduates, with the gap for those educated to GCSE level at $11 \%$. Since this research, pay levels more widely have continued to lag behind inflation. 
Employment rates continue to be higher for the white majority than for ethnic minorities (75\% compared to 59\%). In 2015, analysis released by the Labour Party indicated that there had been a 49\% rise in long-term unemployment among 16-24 year olds from BAME groups since 2010. In contrast, youth unemployment among young white people fell by two percentage points during this period. These findings were corroborated by the EHRC who found Pakistani/Bangladeshi women were less than half as likely to be in employment as the average UK woman. The study also found that Muslims experienced the highest unemployment rates and lowest hourly pay, while Jews have experienced the highest fall in employment rates of any religious group since 2008 .

A large-scale survey conducted by Business in the Community indicated that bias against BAME minorities in the workplace persists, with extensive evidence of racial harassment, underrepresentation at every management level and barriers to opportunity despite greater ambition to progress. Campaigners have called for the government to show the same commitment to tacking ethnic inequality as they have to addressing gender imbalance. For instance, ministers have been urged to push companies to increase the diversity of FTSE 100 boards, or to require the mandatory disclosure of ethnicity pay gaps by companies, a change that has been implemented for gender (see Chapter 5.4). The Greater London Authority reported a median ethnicity pay gap of $16 \%$ between its BAME and white workforce. The government commissioned the McGregor-Smith review into race in the workplace in 2017, and then launched a review into measures the first review recommended in February 2018. But ministers have so far ruled out legislation on enforcing change.

\section{Conclusions}

Conceptions of what counts as equality between ethnic groups have changed a great deal in the last decade, and much of the previous elite complacency towards the difficult issues around living in a multicultural society has been punctured. The UK's record of legislating against discrimination within its territory is generally a creditable one but the implementation of improvements in inequality has been slow. Policies relating to immigration, borders and citizenship, together with some aspects of policing and imprisonment, continue to affect different ethno-religious groups unevenly. This partly reflects an increasingly polarised political climate and media landscape around immigration. The Windrush scandal also demonstrated how easily new or disguised forms of officially implemented racial or ethnic discrimination can arise in this environment.

Sonali Campion is a former editor of Democratic Audit and the UCL Constitution Unit blog. She now works at the Commonwealth Secretariat.

Ros Taylor (@rosamundmtaylor) is Research Manager on the LSE Truth, Trust \& Technology Commission and co-editor of LSE Brexit blog. She is a former Guardian journalist and has also worked for the BBC. 